\title{
The Glutton
}

It was midnight when Olga began to cough again. The men and women in the beds next to her, behind the cupboards and across the other side of the big hall where the refugees were billeted, woke up. Some became impatient and hissed at her to be quiet. In the bed above Olga, Attila finally got up. He went to the bathroom to make a cup of tea. The camp administration had installed an old gascooker there for women with small children, so that mothers could warm milk for their babies whenever they needed it. Attila didn't have a lot of faith in these herbal tea infusions. They'd been recommended them to him by some old women in the camp. But the warm liquid did seem to soothe the irritation in his sister's throat. For the next few hours she would cough a little less. The people in the beds around them would be able to sleep again.

How long are we supposed to go on like this? Attila asked himself. For weeks he'd been looking for a place to live, a room with heating, one in which his sister might have a chance to recover. She'd never get better in this big hall, where they had to sleep together with all these others. The air was stale and stuffy from the breathing of so many people. The floor was dusty. Foul-smelling water dripped from the washing, which hung continuously on lines stretching across the room.

It was obvious that he couldn't wait for the authorities to find him some accommodation. He'd have to go and look for some himself.

A camp resident had given him the address of a man in a big house on the outskirts of town, and it was there that he was headed today, to ask about a place to live.

It was about lunchtime when he reached the address. He hardly had time to notice the person in the doorway before he was being asked to come in.

"Well well well, so you're a refugee too?" said the man. "I see, I see, so you're living in a camp? What was that? I see. I was in a camp too. I know. It's a miserable situation. But come on in. I'll 
see if I can help."

With that, he led Attila through a narrow, almost tunnel-like, dark entrance way. On one side Attila found himself brushing up against clothes hanging on the wall, which his eyes, unaccustomed to the sudden darkness, had not registered.

"Please," the man encouraged him, "let me take your coat." Then he pushed open a door and had Attila step into a small room. He pointed towards a chair: "Please, take a seat."

Attila sat down and looked around. The small, narrow room was sparsely furnished. "Well well well," said the man again. "So you're looking for a place to live?" He wheezed. He was a little over forty and fairly corpulent. He sat down opposite Attila. Between them was a table, covered with a stained tablecloth.

Attila looked closely at the other man. He had had to call on a number of people lately, and had arrived at a certain method of sizing them up. But this man was difficult to gage.

"I'm telling you, I've been through the whole thing myself, all that searching and begging, and now I've got myself this dump here and my wife's allowed the use of the landlady's kitchen." He wheezed again. "That's important. There might be a little trouble sometimes, but that's just life. Nothing compared to back at the camp! Wouldn't you say?" He looked towards the door. "By the way, she'll be here in a minute, to bring us some food. Of course, you'll be eating with me." He said all this as if he had been expecting Attila.

Attila was still observing his companion. The man's face was bloated, with a sprinkling of red pimples across his cheeks, his neck was extremely fat and his upper body was crammed into a striped shirt, not altogether clean by this stage. His sleeves were rolled up and his brown arms folded on the table in front of his chest revealed a profusion of dark hair.

"We're having a nice juicy bit of pork," said the man.

Attila looked past him into the next room. There were two beds, placed end to end. There would have been no space to put them next to each other in the confined space. There was a large wardrobe, painted green, whose top was stacked with jars of preserved fruit and jam; Attila could see large boxes under the 
beds. Next to the only window, he could see a few large bottles filled with different coloured liquids. Schnaps, he thought. And he kept thinking to himself: can this man really help me? How? He hardly seems to have made it far himself. I shouldn't have come here. Novak should have known what sort of a man he was. What did he think he was doing, telling me to come here like that?

His train of thought was interrupted. The man on the other side of the table took out a packet of cigarettes. "Do you smoke?" he asked. And then he repeated, with a twinkle in his eye: "We're having a lovely bit of pork! You do eat roast pork, don't you? Or doesn't pork agree with you? Well, it doesn't with some people, you know. Poor bastards, that's what I say."

Attila lit a cigarette. What could he say? He'd come to find a place to live. What did Novak think he was telling me? This was all hopeless. "I eat everything," he said. "But I really came to see you about helping me find some accommodation. You know, Novak..."

"Yes yes," the other man interrupted. "You're in a hurry. You haven't been here long, have you?" He sounded bored. He got up, walked over towards the wardrobe and took out a bottle of spirits and two glasses. He only opened the door of the cupboard a fraction, but it was enough for Attila to see that only a few shelves contained clothes and that the remaining ones were stocked with tins of sardines and preserves of all kinds. He fancied he could see the bright skins of oranges gleaming from the top shelf. The man returned to the table. Attila saw now that he had slightly bowed legs, encased in a pair of old-fashioned chequered trousers. These were held up by a pair of well-worn, somewhat greasy braces.

"First we'll take some sustenance," said the man, as he filled the glasses. "Three star cognac!" He smacked his lips. "You can get much better of course. But just have a taste of this one before you make your mind up!" He winked. "I like to drink a glass or two before I eat. Prost!" He put the glass to his lips and emptied it in one go. Attila followed his example. The man refilled the glasses immediately. "Prost!" said the host, and lifted his glass again. Attila hadn't had any alcohol for a long time and he felt a sudden intense heat in his stomach. Again the man emptied his glass in one 
go. This time Attila drank only half.

No sooner had they put their glasses down, when the door opened and a woman entered. The man was still licking his lips. She was carrying a large tray of plates and bowls. She said hello and looked curiously in his direction. The man, who had got up when she entered, took the tray from her immediately. He set the crockery down on the table and snapped at the woman: "Can't you see? Another setting! Go and get another place setting!"

When she had brought it, he nodded towards Attila: "Please, help yourself."

The woman stood by the door. The man took no notice of her. She seemed to be awaiting further instructions from him. The man grabbed a spoon, took some rice from one bowl, salad from another, speared a big piece of meat from a small pan, and repeated his invitation to Attila: "Come on, get stuck in. You'll like it."

When he noticed that Attila was still staring at the woman, he dismissed her abruptly. When he was alone again with Attila, who was helping himself hesitantly, he explained to him with his mouth already full: "She's a wonderful cook, I'm telling you, just wonderful. But don't think that's why I married her. No, I didn't even know that then. Honestly. Perhaps I'll tell you some other time how it all came about. But I do appreciate it nowadays. Here, have some more. How about some of this salad here. Salads are her speciality. Oh yes they are! And her cakes! She puts ground hazelnuts and almonds into the mixture and covers it all with a marzipan-brown coffee icing. Yum!" He smacked his lips again. "You'll see for yourself. Superb!" While he was speaking, he shovelled enormous mouthfuls onto his fork which he swallowed greedily. He spoke with his mouth full and smacked his lips from time to time, as his gaze danced across the table from one bowl to the next. And every now and then he would put a piece of meat or an egg covered in mayonnaise onto Attila's plate and say: "Here, have a taste of this."

Attila was completely confused. But the other man seemed satisfied when he saw that his guest liked the food.

Attila was thinking that his host was not the sort of person who would be able to find him anywhere to live. But at least he had a 
full belly for once! These were things he hadn't tasted for a long time. Today I'll be able to give my camp rations to my sister, he thought. But the man's wife. She'd just stood there in the doorway, like some sort of maid. What sort of a relationship was that? Was she so slavishly dependent on this man, that she would just stand there, awaiting his orders?

An order was soon forthcoming. Shortly after the man had finished a largish piece of meat and some more salad, he suddenly flared up and cried out: "Maria! Maria!" He turned towards the door. "Maria! You've forgotten the wine! How the hell did you manage to forget the wine?" He shouted again: "Maria! Can't you hear me?" His face turned bright red and he waved his fork threatingly about in the air like a weapon.

"It's all right, here it is," said the woman who had come in with a two-litre bottle and two glasses. She filled the glasses for the two men and placed them down in front of them.

For the first time, Attila got a good look at her. She was perhaps a little over thirty, had very black hair and dark eyes. Her skin was a hazelnut-brown colour, and her taut arms were bare under her sleeveless dress. When she left the room, Attila followed her secretly with his eyes.

"Prost!" said his host. He seemed to have regained his joviality. He hadn't noticed his wife, nor Attila's covert glances. He raised his glass, wiped his greasy mouth with one of several paper serviettes lying on the table, and finished the wine in long gulps, slurping and gurgling the liquid in through the corners of his mouth.

"Is your wife not eating?" asked Attila.

"My wife?" asked the man in surprise. "Oh well, she hardly ever sits up to meals, she eats out there in the kitchen or wherever. I found it strange when we were first married, and sometimes I even got pretty angry about it, but as time went by, I got used to it." The man raised his eyes from his plate and glanced across the table towards Attila. "But drink up," he said. "I want to fill the glasses up again."

He had filled his glass already, and proceeded to top up Attila's, who had only half emptied his. He ate a little more and finally put 
his knife and fork back down on his plate.

"Well, are you full at least, Herr... well then, imagine that, I don't even know your name."

"Horvath Attila, please," Attila belatedly introduced himself.

"Aha. My name is Ferdinand Pokorni, my friends call me Ferry," replied his host. "So how did you like the food, Herr Horvath?"

"It was amazing, Herr Pokorni, really good."

"Well, in that case, we'll see what there is for seconds." He had emptied and filled his glass a second time. "Maria! Maria!" he shouted again. But this time his shouting was unsuccessful. The woman didn't appear. Pokorni stared into his glass with a vacant expression, and emptied it for a third time.

Attila had taken only a small sip from his. The wine was strong and he wanted to keep a clear head. He was still vaguely hopeful that the man might return to the reason behind his visit. He tried to prompt him a little: "I have to say, Herr Pokorni, that you really know how to entertain your guests," he began carefully, "and I can see that you've managed to make yourself pretty comfortable here too, it looks really good." He looked at the wall next to the beds. The wallpaper, a dark green pattern of cherries and two pecking birds on a light green background, was slightly faded above the duvets, and the wall was scratched a little. Just above the scratches hung a few small pictures, one in a gold frame, which appeared to be Herr and Frau Pokorni's wedding photograph. Two young people, nestled closely together, smiled out at him. The man had a small student cap on his head. and across his chest he wore a multi-coloured ribbon. The woman wore a white dress and a long veil. Her face was that of a flighty little schoolgirl. Horvath could see little resemblance to the woman who had brought the food. A little higher on the wall, in a thin black frame, was a cheap print of Albrecht Dürer's praying hands. Above the second bed, nearer the window, also in a gold frame, Attila could see a picture of two tall greyhounds and a well-dressed man playing the flute in a richly furnished, candle-lit room. It was a colour print, slightly faded without any glass to protect it. Finally, right next to the window, was 
a small picture: a man's head, quite dark, maybe a postcard of a painting by Rembrandt. "It's not as if I'm in any position to make judgements," he thought. But at the same time he was thinking "I'd never decorate any room of mine like that. The pattern on that wall is hideous. It's so dark! And as for all those pictures! But all he said was: "You've given me hope, Herr Pokorni."

But the host waved it all aside. He refilled his glass. His hand was already trembling slightly. "Where's that woman with the gateau?" he mumbled.

Attila returned to his topic: "It really is pretty unbearable in that camp. I'd be really grateful if you could help me, I really would."

"Prost!" said Herr Pokorni and emptied his glass again. "So, what d'you think of that wine? Pretty good, wouldn't you say? Oh, yes, just you wait. I've got something in mind for you, trust me." He smiled as he spoke. "But don't be so impatient. I suggest we should have a go at the gateau first. We could have coffee with it. How would you like that?" He got up and and prepared to leave the room. "I'll have a look in the kitchen, see what the matter is with the gateau, why it hasn't come yet." He took a hesitant step away from his chair, which he had pushed from the table towards the door. Now he seemed to think better of it. He sat down again. His gaze was vacant, and settled again on the glass in front of him.

"Shall I go and have a look?" suggested Attila.

Pokorni's face lit up. "Yes, please. That would be very nice of you, Herr, Herr Horvath. The gateau. The coffee!" It was as if he had been waiting for Attila to make the offer.

Attila got up and left the room. All he could see in the narrow entrance-way was a collection of clothes on one side, and a door on the other.

The kitchen, he thought. He knocked, and when he didn't receive any answer, opened the door. He wasn't mistaken. It was the kitchen.

A mixture of different scents hit him. Onions, garlic, lemon, the smell of baking. With the scents came a wave of warmer air. He closed the door behind him and looked for the woman. She was standing at the window, looking down at the street. It was clear that she hadn't even noticed his entrance. 
Funny, he thought, I wonder what there is to see. He crossed over towards the woman in order to look down at the street as well, but stepped on a piece of lemon rind which must have fallen down from the table, and slipped. He saw the street only for a moment, a moment too fleeting to be able to make out any details, then, like a reel of film coming to an end, it all just slipped away. His head passed dangerously near the window-sill, and his hands instinctively grabbed at the hips of the woman in order to steady himself. He saw the cross-bars of the window slide up to the ceiling, the head of the woman followed, until he found himself supported by her body. He straightened himself up, embarrassed, and looked around, as if searching for something.

The woman had turned immediately at his touch and looked at him in surprise, almost angrily. What do you want, how did you get here? her eyes seemed to ask.

"I'm sorry," he said, "I," he looked at the floor and noticed the lemon rind for the first time, "I lost my footing on that lemon rind there. Please don't get the wrong idea. I'm really very sorry." As he spoke, his glance slid from her face down to her hips. She laughed, showing white teeth, like those of a wild animal, and her eyes, wide open and fixed intently on him, made him feel uneasy. He stood beside her. He felt her breath. He inhaled the scent of her hair. Again and again, his glance strayed back to her eyes, but he couldn't hold her gaze. His eyes wandered instead over her face and neck and down her body.

He had come into the kitchen to get the gateau and the coffee. Why did he now find himself staring at this woman? Why did his glance always seem to seek out her eyes? She was his host's wife, the wife of that fat, drunken man who had fed him today, who had offered him his hospitality. Who had forgotten at first even to ask his name. Why was he staring at her like this? He had put his hands on her hips to support himself, involuntarily and unconsciously. He had almost fallen to the floor. And now it seemed to him almost as if, with that one simple action, he had in fact lost all sense of balance, and that he was sliding faster and faster and deeper and deeper into a pit of longing, a state of uncontrollable desire. He had come for the gateau, and this pair of eyes was no concern of his. 
His action had been a mere reflex, and at the moment when he had gripped her body he had felt nothing more than support, the same sort of support he would have felt had he gripped the timber of the window-sill. But it hadn't been the window-sill. It had been a woman's hips. It was life. He had come for the gateau. But his hands had ended up elsewhere. The place where his hands were still resting. His eyes traced along her body again. And then those eyes! Those dark eyes which fixed him in their gaze, they looked at him as if his hands had already said something, something his mouth didn't dare to say. No, he had come for the gateau and the man in the other room, he might be drunk, but he'd be waiting for him, waiting for that gateau. That man who had invited him in and fed him, that stranger, all because Novak had sent him, that man would be getting impatient by now.

"The gateau," he croaked, almost inaudibly. But he corrected himself immediately and began to explain quickly, as if he were afraid of saying something quite different, something which might seem to him more appropriate for the moment, something he had to repress: "He sent me to get the gateau!" He had meant to say: 'your husband', but for some inexplicable reason couldn't bring himself to say it.

And he continued on, as if trying to break down that nebulous something which was building up such a dense atmosphere in the space between his eyes and hers, between his hands and her body: "He wanted me to get it. Please don't think that it was me... I would never dream of doing such a thing. But he... you see, he asked for the gateau. He said your baking was amazing. He's very proud of you. He's been praising your culinary skills. He's a nice man, a good man. All I did was ask him for some information and all of a sudden he was inviting me to lunch. You know, I came to look for a place to live. I think he's going to help me. $\mathrm{He}$ promised. He wants to help me." At the mention of a room, Attila thought of his sick sister: "A room like the one you've got would be all I need. I'm staying at a camp with my sister at the moment, you see. It's horrible there. Unbearable actually!"

It all gushed out so quickly, as if he had learned it off by heart, as if he was afraid of forgetting something. Now he was silent. 
The woman made no reply, but remained staring at him with wide-open eyes.

Attila had stepped back and now he gazed around the kitchen: "Do you really never eat with him?" he asked, without knowing exactly why those particular words passed his lips. He turned towards the woman again. Again, a tense familiarity seemed to rise up between them.

"No," she hissed. This was the first word she had spoken to him. "I never eat with him, with that bottomless pit. Can't you see that he only wants to impress you? He's not interested in whether you're hungry or not. He knows you've come from the camp. That all you get is that monotonous camp food. He wants to show off, show you what's available, and that it's all part of his daily diet. But of course," her voice suddenly became loud, "he's a good man. Go back to that good man, off you go! You'll find the gateau over there on the bench. Carry it in to him and stay with him. He might even offer you my bed, it wouldn't surprise me! Oh yes, he's generous all right. But please, don't hesitate to accept his offer. Take it. I haven't slept here for a long time. Go away! Go!" She gestured for him to take the gateau and leave the kitchen.

The door closed behind Attila, leaving him surprised, and at the same time, disturbed. In one hand he held the cake, with the other he felt along the collection of hanging clothes for the door.

What a mess. Hadn't he seen those eyes transfixing him? Why had he even mentioned the gateau. He felt like smashing it into one of the coats or throwing it to the floor. And then the way he'd started talking about that man! It was too stupid for words! Suddenly, he could smell the chocolate icing, and strange as it seemed, it reminded him of the scent of the woman's hair, and he felt that he couldn't bear the scent of the chocolate alongside that of the hair. He had to get back to the room as quickly as possible and get rid of the gateau.

The man at the table raised his head when he opened the door. Attila noticed that Pokorni had nodded off while he was in the kitchen. That made it just perfect. But the man's face came to life again immediately when he saw the cake in front of him. He grabbed a knife at once and began to cut it into several pieces. $\mathrm{He}$ 
put a large slice on a plate, set it down in front of Attila, and began to devour the rest. He smacked his lips, made clicking noises with his tongue and snorted. They were the only sounds in the room.

Attila had taken his seat again. He perched on the edge, as if he might have to leave at any moment, and didn't say a word. Neither could he bring himself to eat the slice of the cake in front of him.

Every now and then Pokorni would mumble: "Hmmm! Mmm!" His glance alternated from the cake to Attila and again from Attila to the cake. His gaze was hazy and his movements uncertain. Finally, he twisted his chocolate-covered mouth and leered in a seedy kind of way.

He knows everything, thought Attila. But what is there for him to know? Is there anything to know other than the fact that Attila went to the kitchen, slipped on a piece of lemon rind and almost fell, that he asked for the cake and left again? Was there anything else to know? Even if Pokorni had come with him, there would have been nothing else for him to see. So why was he laughing in such a covert, knowing manner then?

It was very quiet in the room and Attila thought of the woman in the kitchen. He wondered which of the two beds over there was hers. The one with the picture of the flute-playing man and the little postcard above it, or the one with the picture of the praying hands just above where a sleeper's stomach would lie? Her stomach? And the praying hands above it? And the man with the horizontally protruding flute, the two greyhounds with their bushy tails! It was all so absurd. Attila didn't even want to think about it. $\mathrm{He}$ looked at the fat, shiny, squat face of his companion, and its inscrutable smile. The praying hands. Her belly. The squat, shiny face with its lolling, lapping tongue.

"I've got something for you," said Pokorni. "A great apartment, but I want you to eat a bit of your gateau first. I'm telling you, it's good all right. That's my wife for you! She knows how to cook! Come on, eat it up!" Chocolate was sticking to the corners of his mouth.

To Attila, it seemed like some sort of punishment to have to eat any of the gateau, the sort of thing you might tell a child: You can go and play, but you have to do your homework first, or first you 
have to eat your soup. That sweet smell. He found it nauseating.

"Just finish your gateau. You'll see, it'll be worth it," repeated Pokorni.

"I'm so full, I've got no room left for any more," said Attila.

"Easy enough to say. There's always room for more."

"It's just that, well, I can hardly believe that I might be lucky enough to get to leave the camp."

"But just look at me," returned Pokorni, with a broad grin, "See what I've got. It's not exactly a palace here. But we've got room for all the most important things. Well, I admit, sugar and coffee have to be stored in boxes under the beds, well, and the rice does too. It's a bit inconvenient if you need to get at them. You have to get down on your knees. Ha ha! But that's Maria's job." He laughed again. A thin thread of saliva dripped down from one corner of his mouth. "But in the camp? That kind of stuff just ends up getting nicked there. We didn't start off like this either, mind you. You've got to be patient, but as they say, the appetite grows with the food. Wouldn't you agree, Herr Horvath? All right then, so why don't you just have a bite of your gateau. And people like us, we've got to help each other out. Don't you think? We've got to stick together."

Attila thought how his first impulse had been to smash the plate and gateau on the entrance-way floor. But what could he do now: he had to eat. He helped himself. It was good. It would have been too silly for words to smash a gateau like that on the floor. "I' $m$ not alone, you know," he explained while he ate. "I've got a sick sister too, and that just seems to make everything that much harder. No-one wants to have sick people around."

The other man lolled his head the way a slightly drunk person might loll his head. He snorted. 'That doesn't matter. That doesn't matter in the slightest. Someone will look after your sister. You can have as many sisters as you want and they can all be sick too. Noone around there gives a damn about anyone else. It's a small hotel you know, in one of the remoter districts, down a side street. Noone takes much of an interest in it, not even the police." He grinned. "At least, I've never seen police around there. Not a 
glimpse of them. And we stayed for quite a while, it must have been quite a long time. That was before we found this place."

Attila stared at him. He couldn't be serious, he thought, they couldn't possibly afford a hotel room.

"I see," he said. "It must be pretty expensive though!"

Pokorni made a dismissive gesture. "The rent's not much. The only problem is that it can't be permanent. The management doesn't exactly appreciate clients who stay too long. But if you mention our names, my wife's and mine, they'll leave you in peace for a few months. And while you're there you can look for something more suitable. Come on, we'll help you. Me and my wife. We've got to stick together, eh?"

Attila didn't quite know why. And he was still sceptical: "You're going to organise a room for me in a hotel? All the hotels are full. Except for the big ones. But those are completely out of the question for us." He looked around the room again. Depressing how tastelessly it was furnished.

He looked back at the man sitting opposite him. All of a sudden he seemed to find this Pokorni fellow completely repellent. What was he? A narcissistic glutton. We've got to stick together, he'd said. But why on earth should we? Where did he come from? I don't know the first thing about him. All he's talked about so far is food and drink. He's done nothing but smack his lips and slurp his way through piles of food and drink.

"They've always got room," Pokorni interrupted his reflections, "it's all part of their special service, if you know what I mean?"

Attila didn't know at all. He was too angry. He was disappointed.

"It's down a small street, near the Schnellbahn. My wife will take you there," said Pokorni.

Attila was startled. The woman was to take him there? That woman, that woman with the dark eyes, with the black hair and the smooth skin. Where had the thought of smooth skin come from? What could he possibly know about her skin? Had he touched it? There was no way he could have touched it. He hadn't touched her at all. Just the material of the dress on her hips. An apron, maybe she'd had an apron on too. No, it was no good. Or maybe it was good after all? 
"What's the name of the street?" he asked, just in case.

"That's the problem," said the other man, and looked vacant. The thin thread of saliva from the corner of his mouth had found its way across his chin. "The name of the street, the name of the street, I've forgotten it." Speech was becoming increasingly difficult for him. "We lived there three, four months, maybe even longer. Then again, maybe it was eight... you know... But... well, it happens... the... the..." He was unable to continue. "Well, I don't know. I've forgotten the name. But don't think I can't find my way there. We can both find it, my wife and me. We'd find it blindfold. That's right, blindfold." He yawned, stretched his legs out and shrugged his shoulders. "You see, yes what was I going to... Ah yes, that was where we met the people who helped us on our way. But when you don't know anybody here," he was speaking with his eyes closed by now, "there's no way you're going to get on in life. Believe you me, no way." He shook his head as if to emphasize what he had just said. He opened his eyes wide. "Like I said before, my wife will take you there. Yes, she'll take you. You can depend on her. I can't do it myself right at the moment. I... I've got a lot to do." He yawned again, and brought his hand up to cover his mouth just as it was closing once more. "That's right, Herr, Herr... a lot to do. Man does not live by food and drink alone, you know."

That must be an invitation to leave, thought Attila.

"Maria! Maria!" the man shouted. This time the woman appeared immediately. "Maria, you know that I'm pressed for time right now," said Pokorni. He looked down at his watch for a minute, but seemed unable to figure out the arrangement of the two hands. His tongue seemed to find speech difficult, and when he began to talk again, he looked more at the table than at the woman waiting by the door.

"This is Herr, Herr..." Pokorni started again.

"Horvath," supplied Attila.

"Yes, of course, Herr Horvath. He's in the same position we used to be in once... well, you know what I mean. He's a refugee, he needs accommodation for himself and his sister. In the Golden Apple Hotel. You know they think highly of me there, especially 
the manager. You know he thinks very highly of me. Go and take Herrn Horvath there. Give the Herrn Direktor my regards, and ask him to be good enough to give Herrn Horvath a nice room... cheap, of course!"

He got up, propping himself up against the table. "Good luck, Herr Horvath, and come and visit us again some time." $\mathrm{He}$ stretched out his hand.

Attila looked into the puffy, pustule-covered face in front of him. "I'd love to," he said and shook hands. He tried to catch his host's eye. They seemed to be swimming indistinctly in a glittering liquid and wobbling, like a blancmange in custard. They were the eyes of a good-natured drunkard. They were the eyes of the very first person he had struck up any sort of relationship with in this city. A person he'd sat at a table with. Who had, without knowing anything him about him, invited him in, a man whose wine he had drunk, whose sumptuous meal he had eaten. This man had pimples, was bow-legged and perhaps a miniature dictator in his own house. Above all else he was a glutton, but he had still welcomed him the way one might welcome a friend or a relative. Pokorni was still shaking his hand. He was shaking it quite vehemently, and had put his left hand on Attila's shoulder. "Goodbye. Good luck. And come again."

"Goodbye, and thank you very much for your hospitality," said Attila. For the moment, he had forgotten the woman at the door. He was remembering the friends of his youth, remembering how he had said goodbye to them, and how they had parted. He thought of his homeland. He felt a slight choking in his throat. He turned around. The woman opened the door for him and he stepped out into the entrance hall beside her.

Behind him he could still hear the faint thud of an ungainly body and the groaning of a chair. 


\section{In the Golden Apple Hotel}

Attila wanted to help the woman on with her coat, but she was too quick for him, and made a defensive sort of a gesture. She locked the apartment behind her, and they walked down the stairwell and out into a gloomy, foggy early afternoon. Neither of them said a word. Attila didn't quite know how to behave. When they arrived at the door to the building, he finally felt compelled to say something.

"The weather's pretty bad today," he began, fairly unoriginally.

The woman didn't respond.

Attila tried again: "I feel terrible that you have to come out with me in this weather. There's really no need. Couldn't you just tell me where the hotel is? I'm sure I'd be able to find it."

They had stepped out onto the street. People were flooding past. Tyres hissed on the wet asphalt, trams signalled with their bells and rattled noisily past. Every now and then an impatient driver would sound his horn. Although it wasn't raining, the humidity was so high as to be almost palpable. The sun projected a circular halo out from behind a silver metal disc. The walls of the houses glinted damply. They looked like the mangy, mottled skins of toads.

"Let's go," said the woman. Her walk was soft but confident. She was well-dressed, her appearance set off by a light-blue winter coat and a fashionable little hat.

Attila was only too aware how out of place he looked beside her in his stained coat.

"You probably had plans," he began again. "I'm sure you would have rather stayed at home." They stopped at a crossing. The lights were red.

"At home?" asked the woman. "What do you mean, at home? Only that man's fevered imagination could make any sort of 'home' out of that closet of an apartment! 'Home' is just a word, just a word like all the others. At home indeed!" She spoke rapidly, as if she had to set Attila straight before the lights changed. "How could anyone feel 'at home' in that miserable hovel he calls an apartment? Oh forget it." She turned toward the traffic lights. It 
seemed she had nothing more to say. But then she began again. Very suddenly and very vehemently. There was a hostile tone to her voice: "Once upon a time I believed all that as well," she waved towards the people waiting next to them, "but not any more. Look, it pursues you. Wherever you go, it follows you. And look here, these faces without any expression, you meet them everywhere, even inside your own four walls, when you sit up at the table and when you lie down in your bed and the light from the advertising on the building opposite reflects into your room. Green and red, green and red, over and over. And then when a face bends over yours, its eyes reflect green and red, again and again, and your hands tremble just like these machines waiting here, whose engines have been throttled back and who are just waiting to take off again. But what's it all for? What's the point? You think that once you've been integrated into this society, once you've got yourself a flat and a car, just like all these other people here, you think that you'll be satisfied. I thought that once too. But then suddenly you find you've got everything and somehow, somehow you're still not satisfied."

Attila was taken aback by the aggression in the woman's voice. What was the matter? Why was she so dissatisfied? She didn't look as if she had any reason to be so unhappy. She continued on: "I suppose in a way that Pokorni is better off, when you look at it like that. He immerses himself in his meals, fills himself up with wine and then lies down and sleeps. He's never known anything else. Eating and drinking was always his vocation, even back there. And here, well, it's nothing out of the ordinary here, that's for sure!"

The traffic lights had changed, orange and then green. They could cross. They walked amidst a broad stream of people. He could smell the body odour of the other pedestrians, they were so closely crammed together. Blue smoke from the exhaust pipes wafted above their heads. A truck stacked with coal was forced to wait. Men with blackened faces sat in the driver's cabin and stared down at them.

Attila had listened to the woman without interrupting her. Why was she telling him all this? He was a stranger, a nobody. Was it because of his hands? Was it because of that pair of hands which 
had inadvertently sought support on her hips? Had his hands joined - had he held her? Her eyes! He kept seeing her eyes in front of him. There they were, amid the exhaust fumes and the blackened faces of the men, her eyes.

But all he said out loud was: "Were you ever like us, without a thing to your name? Without even the most basic of possessions? In a refugee camp?"

He looked over at the profile of the woman walking next to him. Her dark hair rested on her light-blue collar, she carried a small, dark-blue leather handbag over her left arm and her hands were encased in gloves of the same colour. If you were, it must have been quite a while ago, he thought. It's easy enough to talk when you look like that, when you've got everything you need and more besides.

They stopped in front of a shop and looked through the window. There were pottles and jars, tubes and bottles, perfume-bottles, brushes, lipsticks in all colours and scented soaps from lavender to tobacco. "Without the most basic things?" the woman took up the question. Her eyes wandered to and fro, from one thing to the next behind the thick glass. "Of course, just the clothes we stood up in. But tell me, has your sister got a lipstick? A compact?"

"What? Lipstick? I don't know. I don't think so." Attila laughed.

"Wait here a moment." She opened the door of the shop and disappeared behind the large dull pane of plate glass.

Attila wanted to tell her how unnecessary that kind of thing was for people in their position. But it was too late. He stood alone in front of the large plate glass window and looked blankly at the display of goods behind it. It was a jumble; round, angular, oblong and oddly shaped objects. With the woman's abrupt departure, he seemed to have lost all sense of connection with the things spread out in front of him. He could see green, yellow, a lot of red and some orange as well; cubes, discs, pillars. A large abstract painting, whose meaning he could not decipher. Finally, all he saw was the glass in front of him, and his figure reflected in it, alone and lost. Behind him, passers-by fluttered past, like large grey bats.

Maybe she's right, he thought. Maybe it's true that human 
beings are never happy with what they've got. All he needed to make him happy was a room for himself and his sister. Discontent and unhappiness! But then, wasn't that the very impulse that lay behind progress? Wasn't that what started everything off: someone being unhappy with what they had, wanting something better? Freezing in wintertime? That led to the fire. They say a god gave it to the human race, Prometheus. Not being willing to put up with smoke led to the development of the chimney. Dissatisfaction with the dirt of the open fire gave someone a reason to discover heating with gas or electricity. Discontentedness. Dissatisfaction.

"Here you are." The woman had stepped up beside him again he hadn't heard a thing - and presented him with a small package. When she slipped the string over his finger, her finger brushed against his. He raised his eyes. He looked into hers. It was almost as if this casual touch had snapped an electric circuit shut; as if the touch of skin against skin had activated something which had been brooding there since their meeting in the kitchen. He took her hand and tried to keep it in his.

"Thank you very much," he said, meaning to thank her for the parcel. But he noticed that she didn't take her hand away. They stood next to each other in front of the shop window a minute longer. He saw his reflection again, and was embarrassed. Here he was, in his scuffed shoes with their crooked heels, his frayed trousers and threadbare coat, no hat and roughly shaven, next to this beautiful woman. He released her hand.

I have to make sure that I get my act together here. I look terrible, he thought.

They walked on. Twice they turned down side streets. The traffic thinned out. Children were sitting in front of some of the buildings, playing with their dolls, others were riding scooters along the tops of walls. The shops were becoming less numerous and didn't have such large windows. Every now and then, they would come across heaps of rubbish piled up in the guttering, and on street corners, remnants of newspapers stuck to the wet footpath, blown there by the wind. The only sound other than the noise of the passing cars, was the radio music screeching from the windows. Everywhere seemed to be playing the same tune, over and over. The buildings 
were low, had stained, smudged walls and filthy window panes.

Finally they arrived in front of a narrow building, sporting a large black sign above its door. THE GOLDEN APPLE HOTEL was written on it, in gold letters.

"Here it is," said the woman.

Attila looked up at the façade. It was a simple building, several decades old. It seemed to have been painted a long time ago. Most of the windows were shut, many had the blinds down.

The man at reception received them in a friendly enough manner, but became less personable when he heard their request. He wasn't sure whether they could let a room for such a long period of time. He'd have to inquire with the management, he decided.

"Good," said the woman, "ring the management. Tell them that Frau Pokorni from the Tourism Office is here, and wants to speak with the boss."

"You work for the Tourism Office?" asked Attila.

"Yes. Didn't he tell you?"

"Who?" Attila didn't know who should have told him. For a moment he thought of Novak, who'd given him Pokorni's address.

"Ferry, of course," replied the woman. She had taken a seat on one of the old cane chairs which stood on either side of a table opposite the reception area. Attila followed her example. Taking the other seat, he produced a crumpled packet of cigarettes from his trouser pocket. He offered the packet to the woman. She refused. "Thank you, I don't smoke."

The man at the counter was ringing the manager.

Ferry, Ferry, thought Attila. Who on earth is Ferry, and what have I ever had to do with him? "Who's Ferry?" he asked, finally.

The woman looked at him mockingly: "Pokorni, of course."

Of course, Attila remembered now, the man had told him that his friends called him Ferry.

The man at reception was still on the phone.

"Is that so," said Attila, "no, he didn't tell me. He didn't really talk about you at all."

The woman had raised her eyebrows. She nodded. "Of course 
not," she said and got up. She moved over to the other side of the reception area, where there was a small glass cubicle with a cupboard, a desk and a chair. The telephone sat on the table, next to a number of large books. A blackboard with an assortment of little hooks hung on the wall. Keys were dangling from many of them. "Well, what did the Herr Direktor have to say?" asked Frau Pokorni.

The receptionist put the receiver down. "Well, as I said, we're not really equipped for permanent tenants. You're most welcome to speak to the manager yourself though." He got up and stepped out of his glass cubical. "First floor, number seven," he said, and crossed over to a small sliding door. He opened it and let the woman enter, pressed a button next to the door-frame and turned back towards Attila. "If you would please just wait for a moment." He returned to his cell and sat down at his desk.

Attila sat there and smoked one cigarette after another. The woman had disappeared too quickly for his liking. Now he looked around the room. The table was covered with a patterned sheet of plastic, singed in several places from hot falling cigarette ash. Next to it was a second set of cane chairs around another table. The floor was covered with a red strip of coconut matting, the walls papered with a green wallpaper, so faded that it was almost yellow. A couple of patches still showed what the original colour must have been. Pictures or shelves must have hung there at some stage. Above his head, Attila could see a print of a view of the town in a simple frame. The name of a travel agent was just legible in the right lower corner. Posters for a well-known nightclub hung on the opposite side of the room. They were illustrated, and one showed a picture of three nude dancers with contorted hips. As Attila looked at them, his mind took him back to the hips that his hands had gripped at lunchtime. He found the memory uncomfortable in connection with this picture, and tried to think about something else. His eyes continued to wander. Next to the door of the lift there was a sheet of paper covered in small print, and fixed to the wall with four drawing pins. HOUSE RULES it said, in capital letters. Attila couldn't decipher any more from this distance. His glance slid back to the naked dancers, but his thoughts were already occupied 
with other things.

He thought of himself, sitting here like a beggar, and he also thought of his sister, coughing in her bed back in the camp; he thought of last night, and the annoyance of the people woken up by her coughing.

"Please, take a seat." Up in room number seven, the hotelier, a tall man of about fifty years of age, was talking to Frau Pokorni. He pointed towards a leather chair. Before the woman had entered he'd been sitting at his desk, where a bottle of gin and a few glasses of different sizes nestled amongst telephone, piles of paper, accounting equipment and writing utensils. He was now standing, and offered Frau Pokorni his hand.

After she had taken a seat, he arranged a chair for himself and sat down opposite her. Between them was a small round table covered with a dirty grey lace cloth. "Well well well, my dear woman," he began, beaming, "I'm delighted to have you visiting me again in my humble hotel. I don't think you've honoured me with a single visit since you moved away from us. I did so ask you for one, and I thought you had half agreed in the end." His voice assumed an accusatory tone, and he bent his upper body slightly so that his face was nearer hers. His breath carried a wave of alcohol towards her. "But I understand. You didn't want to come here by yourself," he continued. You've really thought this out very thoroughly. A brilliant excuse today. Masterful. Don't you want to take your coat off? How inconsiderate of me!" He got up and attempted to help her off with her coat. The woman waved him away. He sat down again.

"My dear Herr Direktor, you misinterpret the reason for my visit," she said, with an ironic smile. "You know that I hold you in the highest regard, and how much I enjoy your company, but today I've come on behalf of that poor man downstairs and his sister. They need a room. You'll give them one, just like you did for us, won't you? You helped us too, you know, you didn't ask who we were or what we looked like, did you? By the way," she added quickly, when she saw the man opposite her lean back and cross his legs, "the two of them will need our help for some time. My husband has taken them under his wing." 
The hotelier grimaced. He looked as if his teeth were grinding on some invisible matter. He got up, walked to the table and filled two glasses with gin.

Meanwhile the woman kept on talking. "Yes, and that's why I'll need to come around here fairly regularly. I hope there won't be any problem with that. I don't really have time to even take my coat off today. But we should be able to meet again soon."

The man stood before her with the glasses in his hands. "Don't you even want a drink?" he asked. She got up and took a glass. He moved closer to her. "Maria, how much longer? How much longer are you going to let this creature dominate you. Your husband! He isn't your husband at all! You're not Frau Pokorni! He's a lazy bastard, a sorry excuse for a man who would have turned to crime long ago if it hadn't been for you. I know you hate him. You hate his gluttony, his vanity. Admit it. He only manages to survive because of what you earn. You could have had a decent apartment long ago, a car even, if you didn't have to support that pig of a man. Let him go! Then he'll learn to work. He doesn't deserve any better."

"By the way, he sends his regards," the woman said.

"Idiot," he grunted.

"No, Georg!" she said. The glass in her hand trembled slightly. "You'll never understand. Maybe it's just impossible to understand." She shook her head unhappily. "I don't even understand it myself really."

The man looked ahead gloomily. "No, you're right, I don't understand it at all.

"Georg, there's a lot about our behaviour that we don't understand. Surely you know that by now?" She pitied him. She knew that deep down he was a decent human being. She knew that he really liked her. She thought back to the time when they'd been poor and shy and had found a place to stay with him. And finally she thought of the fact that it was him who had introduced her to those people who had then got her the job at the Tourism Office. He had told her once that he loved her. How many others had he said that to? Was it really true? Or was he just imagining it? She didn't want to dwell on the matter. It was absurd! But then when she 
thought of those big thick lips kissing her and those hairy ape's hands touching her, and she thought of Ferry too. She felt nauseous. She'd had enough of all that.

"You're quite right, there's a lot about our behaviour we don't understand," he said. They were still holding the full glasses in their hands. "Well, what shall we drink to?"

"Your heart of gold, Georg, which will give these two refugees somewhere to stay."

"And yours, which shouldn't have left me alone for such a long time." They raised their glasses, smiled at each other, and drank.

She offered him her hand. "Thank you." She wanted to add: I know that you'll help if you can. But she remembered how hesitant he had been and remained silent.

He accompanied her to the door. "I'll phone the duty manager and tell him. They can have the same room that you had." And as he opened the door, he asked quietly: "Will you come up again before you leave?"

She nodded.

As she walked down the stairs to the foyer, she asked herself what had made her come up here again. She had known full well that Georg wouldn't have forgotten. She had known that, and had come anyway. Or was that maybe why she'd come in the first place? What had possessed her to help the Horvaths? There were thousands of Horvaths and there was no way she could help them all. Pokorni had wanted her to. Was that the reason? Was that the only reason?

Attila jumped up when he saw her coming. He met her at the bottom of the staircase. He could tell, he knew immediately that the news was good.

The duty manager came out of his glass enclosure. The woman had noticed the familiar movement of his hand towards that particular place on the board with the many hooks. Now he approached her with the key. "You know your way around?" he asked.

She just nodded.

A short while later, she and Attila were in the small, modestly furnished hotel room. Two beds, two bedside tables, a basin with a mirror above it, a couch, a table and two chairs. The blinds were 
down. It was gloomy inside the room. It was difficult to distinguish the furniture clearly.

The woman switched on the light. "This is it," she said, looking around and noticing that not much had changed since then. Only the wall-hanging behind the couch was different. Now there was a multicoloured patchwork cloth hanging where once there had been a faded colourless sheet.

"How long do we have?" he asked.

"We didn't talk about that," she answered. "But the Direktor will be sympathetic. You'll be able to stay until you've found something else."

Attila walked over to one of the windows and raised the blind. The view stretched out across the wet roofs of the neighbouring houses. Grey-blue smoke wafted from the chimneys, and in the distance one could make out the shadow-like silhouettes of the mountains. The sky was a uniform grey mass. The woman remembered that on beautiful days the forest was visible, and that in amongst the confusion of roofs, there was one covered in glass, which gleamed like liquid silver when the sun shone on it.

"I don't know, I don't know what to say," he said hesitantly. "You've helped me so much. I am very, very grateful."

"Don't mention it," she said. "It all just happened to work out, and as you'll find out for yourself when you've been here for a while, it's not the sort of place that one can stay forever." She paced up and down the room, then she stopped in front of him. "We managed to stay here for quite a while. Ferry wasn't too fussy and I, well..." She spoke the last words slowly and then broke off abruptly. She thought of Georg. He had drunk a lot less when they'd been living at the hotel. All his life he'd been alone, all through the long years of his exile and also later, after he had returned and taken over his hotel again after all those negotiations. It had been almost completely run down during his absence. The business with those women, the drunken men, the pimps and the police had all ground him down. He had always said that he wanted to spruce the place up a bit, turn it into a respectable bed and breakfast. But it was all just talk. Their mutual friends just smiled whenever he started up on that theme. Their mutual friends, the 
professor in the outer district, the pianist Blumenstock had been there too and young Lindberg, the two Muschlers and a whole collection of other people, who didn't always come. He drank a lot less in those days. But then, when they and the others had moved away, he had turned back to the schnaps bottle. Not that he was addicted, but he drank and he drank too much, that was certain. Of course, he needed her. But she had an aversion to his hands, his lips, and this place above all.

"We shouldn't act," she continued her thoughts out loud. "Action always leads to destruction. We should just lie still, not feel, not desire." She broke off. She fell silent.

Attila could smell her hair near him. He put his hands on her upper arms and bent his head forward. He felt the impulse to say all sorts of words, but then they all seemed stupid and banal. He stayed silent. He would have liked to stroke her hair. But then there was the hat. No, there was just no way. He would have liked to pull her towards him. But there was that light-blue cloth, and his coat with its greasy spots would have soiled it. No, there was no way.

She looked up at him. His face! That straight nose, those thin lips, gently curling at the corners. Those long, narrow fingers! she thought. I can feel every single one of them on my arm! Weren't those hands, that face, the real reason that I came here? Ferry's face, covered in pimples! Georg's ape-like paws. Don't even think about them. This Attila is like a child. He still believes in things, trusts in them. He believes that Ferry, that windbag, has really helped him. Why did he do it? Has he helped him? I'm the one who's helped him!

She didn't take her eyes off him. But he was blind and deaf. He didn't understand what her eyes were saying. All he could hear was the great silence in the room and the muffled noise from the street and he thought above all that he had to be grateful. I mustn't allow this feeling between me and her to rise up again, he said to himself. It would be ungrateful, he said to himself. Ungrateful. Ungrateful, he repeated. Like an automaton, like a machine, he repeated the word over and over in his head.

Finally, after some hesitation, he bent towards her. An eternity 
seemed to pass for both of them, and he kissed the woman's hand. His left hand glided down to her right and pulled it towards his lips. He could feel the smooth skin and she thought for a moment that she could sense his teeth.

"If we hadn't acted, if we hadn't done anything at all," he picked up her last train of thought, "we wouldn't have met, there'd be nothing for you and me to desire."

She expected more, but he remained silent.

Finally he said: "We should get to know each other better. Please come and visit us!"

Get to know each other better? she thought. Wasn't 'getting to know each other better' only another way of distancing oneself? Aren't these fingers on my upper arm close enough? Isn't this trembling silence bouncing between us the most intense closeness that can exist between two people? Was there any point, any further point in wanting to get to know each other better?

In spite of all that, she said: "Yes, I'll come. I'll come back. But I have to go now." She turned towards the door, glanced at him once more, hesitated for a moment. He stood alone and helpless in the room. His hands hung uselessly at his sides. She had already reached the door. He stepped towards her once more. Now, she thought.

But he just shook hands with her again and said: "Thank you, thank you so much for everything."

For a long time he remained by the door, listening. He thought he could hear her steps, and imagined her walking towards the staircase.

But they were the steps of Trixi, one of the maids. Her shift finished early in the afternoon. At that very moment she was walking towards the staircase. Attila stood behind the door and listened, then he made a helpless gesture with his hand, turned around, walked to the window, opened it and looked out for a long time.

After she had said goodbye to Attila, Maria went back up to the manager's room. She wanted to keep her promise and wanted, well what did she want... what else did she want? She didn't quite know herself. 
When she entered the room, it seemed to her somehow more friendly than before. There were flowers on the table. Had she just not seen them before, or had Georg just got them in? Two large, yellow chrysanthemums. Chrysanthemums, which she loved so dearly. And when she looked at Schmidt she noticed a smile on his lips, which gave his face an appearance of relaxed cheerfulness. She thought about how very rarely it was in her life that anyone had given her something without expecting something else in return. But then she also thought about how very rare it was for anyone to even remember what gave her pleasure.

She had taken off her coat, and they both sat down in the easy chairs at the low table. Georg reminisced about the old days, the opera and concerts they used to attend together. Maria felt reassured. Some inexplicable tension in her eased away. Sometimes Schmidt would describe a scene, and in order to make it more concrete, he would gesture with his hands. At those moments, Maria found his hands almost beautiful.

It was quite late when Maria returned to Pokorni from the hotel. She had wondered for a moment whether she should even go back to him at all. But she wanted to pick up a few things. She also wanted to tell Ferry that the Horvaths had got the room. When she entered the small room in which the two men had eaten, he was standing at the window. He stared down at the street. He scarcely noticed her come in.

Maria told him about Schmidt. She didn't mention everything. Pokorni knew anyway.

"It's all such a load of rubbish," he said and kept looking out the window. "The man's an idiot, a whole hand full of trumps and doesn't know what to do with them. Think what we would have made of that run-down old hotel!" He turned around and looked at Maria. "A few years ago," he added. "Now it doesn't matter any more." He walked to the table, sat down and rested his head on his right hand.

"Can you lend me three hundred?" he asked, speaking through the fingers of his hand. "I lost yesterday, I have to pay Novak."

Maria took a few bank notes from her handbag.

He straightened up, looked at her gloomily, took the bills and 
with a fleeting gesture of thanks, left the room.

That evening, when the duty manager took the key from the board, he noticed that the new guest's sole luggage consisted of a travelling bag and some sort of a net filled with unidentifiable objects. A slim young woman, dressed in an ugly brown coat, and with a cardboard box under her arm, walked at his side. 


\section{The Violet-Blue House}

"Hello, Herr Horvath, the duty manger wants to see you!" Trixi shouted into the room, after knocking briefly at the door.

The Horvaths had now been in the hotel for five days. Olga stayed in bed almost all day, and her health seemed to have improved. Some nights she didn't sleep for hours at a time, but she was coughing much less and hoped to be able to get up soon. Most of the time she lay motionless and looked up at the ceiling, watching the different reflections of light. There was the milky light of the street lamps. It was like the soothing swinging of a pram or the rolling motion of a boat in the wind, to and fro, to and fro. Then suddenly, like the striking paws of a predator, the headlights of a vehicle would grip the wall, swing across and disappear again. Some distance away, a coloured light blinked on and off at regular intervals, Olga could just make out its rosy shadow.

She lay in her bed, looked at the ceiling and listened to the night. She registered every passing car. The stopping and starting of vehicles. She heard people laugh and talk. She didn't understand what they were talking about. She heard voices. In the distance, the traffic hummed and droned like a piano accompaniment. Nearby, from outside in the corridor, came the sound of men's and women's footsteps, and sometimes screaming. Then she would hear the trains going past, rattling past, always at the same intervals, always the same crescendoing and decrescendoing sound. She lay in her bed, glared at the reflections of light and couldn't see the point of anything.

She had grown up in an old house, in a cool atmosphere. Now she felt a hot wave of disquiet rising up inside her, even though she had no idea what went on under the roof she now shared. When Attila, who had been tired and slept through the whole night, woke up in the morning, she would often tell him about her dreams.

Once in a dream she saw Joseph who had been sold by his brothers, another time she saw an old man who had undergone much suffering and whose return home was delayed again and 
again. And once she dreamed about herself. She dreamt that she was searching for a house, a house where she had once lived. But all she could remember was that the house was plain and unornamented, and that it was distinguished from all the other houses by its violet-blue colour. She remembered too that a door in that house, leading to a brightly lit room, had been opened and that a child standing next to her had entered the room. Was it the Christmas tree which shone so brightly in the room, or was it a birthday cake with candles? She remembered that it was now her turn to enter the room. She was looking forward to it so much. But then somebody came and turned her head around and then her whole body, faster and faster, spinning her like a top. And in the spinning, she lost sight of the Christmas tree and the birthday cake, even the house and all the other things. She found herself in a strange city, in a strange street, looking for the blue house. There were many houses next to each other. She was very tired from her search, but just couldn't find a violet-blue house. With some houses it was easy, she could see from a long way away that they bore no resemblance to the one she was looking for. But some were very much alike as far as their structure or plasterwork were concerned. Others were so well hidden behind hedges and trees in the middle of gardens that she had to go quite close to look at them. With some houses she even had to inquire with the doorman about their colour, for the perspective she had on the house meant she couldn't tell properly. Once, when it was approaching evening, she had asked about yet another house and the doorman had asked her why she wanted to know. She hadn't known what to say. All she could stammer was: "A violet-blue house." The doorman had shaken his head: "A violet-blue house? No, there's no house like that here, I'm afraid." But he had suggested that she might like to enter his house, because it was beautiful too! At least she should have a look at it. But no, she wanted to find the violet-blue one, and had moved on to the next house. She had the impression that the old man was shouting after her: The houses get a new coat of paint every few years. They were all violet-blue once upon a time, and later on they'll all be red or brown or black. But she had already moved on. She couldn't stop, couldn't go back. That is how dreams work. You can never stop, 
never go back.

When Olga told her brother about her dream, he laughed. You have such weird dreams! A violet-blue house! There's no such thing. And soon he'd forgotten all about it.

As the maid shouted the message into the room, Olga looked anxiously at her brother. "My dream," she said. "We'll have to leave this place."

It hadn't taken Attila long to figure out what was going on in the hotel which gave them shelter. He'd gone to the Pokornis, found only Ferry at home and asked him whether he had known what was going on in the hotel. The man had just laughed, sent him to the kitchen to fetch beer and sausage, eggs and bread, fruit and chocolate, had invited him to eat and of course explained to him that he was much better off there than in the camp. Finally Pokorni had patted him on the shoulder and assured him that he thought very highly of him, and there was no doubt that people who showed an attitude like his would land on their feet very soon. That was what Novak thought too, and if he needed anything in the future, he shouldn't hesitate to ask Novak.

Attila hadn't thought of Novak at all. When they'd left the camp, he had thanked him for the tip and hadn't thought he'd ever see him again. Even now he didn't pay much attention to Pokorni's remarks. He asked tentatively after Frau Maria. Maybe the only reason he'd gone to Pokorni's was because of Frau Maria. But the man didn't know where she was. He promised to give her his regards.

Now, as Trixi called Attila to the front desk, he reassured his sister. Surely they wouldn't have to leave so soon. Frau Pokorni had said so. Again, he could sense the scent of her hair before him. He saw her face.

Olga's worries were indeed without foundation. When Attila arrived at the desk, the old man motioned to him to come closer: "A telephone call for you," he said and handed him the receiver.

"Hallo, Horvath speaking," said Attila. He knew immediately who was calling. He recognised the voice at once. It was Frau Maria.

"I heard you visited Herrn Pokorni," she said. Yes, those were 
her words: Herrn Pokorni! "You were surprised about the kind of place it turned out to be. I understand. But it isn't all that bad. Don't bother with the other guests. You've just got to be patient."

"Yes, I know," said Attila, "I'm being patient. What else can I do?"

The woman on the other end of the line hardly noticed his jibe. "To begin with, you have to take a look around and see how other people live here. No-one has enough room. And there's also the problem that you don't know enough people here. I mean people with influence. You have to establish some contacts first. Contacts, do you understand? Contacts are everything."

"I don't know," Attila said slowly, "I'd really like to... but how?"

"Come on, pull yourself together, Herr Horvath," the woman interrupted him. "You have to get out a bit more. Don't you know anyone here? Your German is quite good."

"But I don't know anyone here and it's so hard, as a foreigner I mean, to fit in..."

"We managed fairly quickly."

"Yes, you did!"

For a moment there was silence on the other end, then the woman asked: "So what do you do all day long?"

Attila was a bit embarrassed. "At the moment I'm delivering newspapers," he said. "But back home I used to make violins. Our family has a reputation with orchestras all over the country. Lots of famous soloists have bought their instruments from us. And not only the gipsy fiddlers, no, the violinists from the state orchestra and the radio orchestra too. Oh, when I think back to those concerts!"

He fell silent. He remained silent even when the woman said nothing herself. He held the receiver in his hand and had his ear pressed up against it, but he didn't hear anything and didn't say anything. He was holding a lump of synthetic material in his hand and a few thousand metres of wire led out from it, led on to another telephone and to thousands of other telephones with synthetic receivers attached to them, which were picked up by thousands of other hands and pressed to thousands of other ears and thousands 
of other lips spoke different words, talked about the weather, about the price of coal, about the movie just about to be released or already seen, about the corner-shopkeeper's marriage, about the secret treaty with the neighbouring state, about Jumpi, the young fox terrier. They called their secretary, the fire brigade or their daughter's tutor. The thin metal fibres which were criss-crossed all through the town transported all these things. They lay, hidden like nerves, underneath a crust of concrete, asphalt or granite, covered with a layer of soil, they lay bundled, wound together and packed in black oakum underneath the streets and paths. Cars drove over them, the trams and large buses and even the massive aeroplanes rolled over them before they took off. Attila had been speaking about his home into this lump of synthetic material. Now he was silent. He had used the same consonants and vowels that the woman at the greengrocer's used, the minister, the canary breeder, the ragman and the kindergarten teacher and all the thousands of other people who sought a connection with other people through this very same line. But he knew that there was no way he could tell the person on the other end, no way he could tell Frau Maria anything about his homeland in this way. So he remained silent.

Perhaps the woman sensed this, perhaps she felt the tension present in his last words and knew that this thin bundle of metallic fibres could only bring her the vowels and consonants, but not his eyes, which were part of every utterance, and not his hands with their slender fingers, and not the air between him and her, which seemed to rise into an almost audible wave when they were standing face to face.

"Tell you what," she continued, "come to my office tomorrow at four o'clock. We'll visit a few acquaintances of mine, perhaps you'll be able to make some contacts there. If you like, you can tell me about your homeland then." She gave him her work address and told him the best way to get there.

Olga felt reassured when her brother told her what it was all about. A violet-blue house. The houses get painted every few years. Each one had been violet-blue at some stage and each one would be red or brown, green or black at some time in the future. Olga lay still and looked up at the ceiling. What colour was the building they 
were living in now? It had been dark when they arrived. All she ever saw was the ceiling, with its mixture of reflected lights. There was the milky, even light of the street lamps, it was like the soothing swinging of a pram or the rolling motion of a boat in a light wind, to and fro and to and fro. It made you sleepy. But then suddenly the headlights of a passing vehicle would grip the wall, like the striking paws of a predator, swing across and disappear. A coloured light blinked on and off at regular intervals, Olga could just make out its rosy shadow. Was the house pink, was it red like the morning? Olga lay in her bed and listened to the world of night. 


\section{The Colossus}

On the evening of the same day, Attila was coming down the staircase towards the hotel foyer, when he bumped into a gauntlooking man. Attila had been about to go and post a letter, and the gaunt-looking man, who acted very awkwardly, almost embarrassed, was in a hurry. It seemed as if he didn't want to have anything to do with another hotel guest. From his accent, Attila could tell that he wasn't a local either. He immediately volunteered that he was a stranger here and that he was just living in the hotel for the time being. On learning this the man seemed somewhat more approachable.

They stepped out onto the street at the same time. The other man looked around and walked beside Attila to the next intersection. As they walked, Attila learned that his companion visited the Golden Apple Hotel very infrequently. He had known one of the women for years, he said, and she was so decent - decent was the word he used - that she let him come and go by himself in order to avoid gossip, in case an acquaintance or colleague from work saw him.

After a few words, Attila realized that this man was different from the other guests he had met up till now in the hotel. Most of them referred to their presence there with an air of casualness or with a loud, overdone bravado. Attila wasn't interested in the details of their dealings with the women. But he tried, as far as he could, to ask the one or the other about cheap accommodation, at the hotel bar for instance, where he sometimes went to drink a small mocha. But more often than not, he discovered that his companion would insist on burdening him with the intimate details of the pleasures he had just experienced instead, and with an almost unstoppable insistence which made Attila very uncomfortable.

This man was different. He was reserved. It almost seemed as if he wanted to make excuses for his visit to the hotel, and wanted to defend himself against some sort of accusation, which in this case didn't exist.

He wasn't loud like most of them were either, but had an air of 
quietness, which bordered on sadness. Perhaps he really was sad. It almost seemed that way to Attila.

They had reached the postbox, and Attila was about to turn around and go back to the hotel, when the other man asked him: "Why on earth are you living in this... well, you know what I mean? And with a young girl too, you say? How old is your sister?"

"Eighteen," said Attila, "she's still very innocent, she's just left school and has no idea what goes on there. There's no need for her to know either. She's sick at the moment anyway, has to stay in bed and never leaves the room. She's a bit afraid of the people, she told me once. You know, she can hear the guests shouting and screaming out in the corridors sometimes." And as he felt that the last sentence wasn't very flattering to his companion, he added: "Not everyone who visits is as quiet and reasonable as you."

"Wouldn't you rather find private accommodation somewhere else?" asked the other man.

It sounded so natural, as if it were the easiest thing in the world. They were standing underneath an electric light which swung slightly in the wind as it hung from its tall dark pole, and this question, as well as his companion's appearance, seemed somehow almost diabolical to Attila. The man was wearing a dark suit which accentuated his long, lean figure. His extremely pale face, finished off with a short black goatee, was motionless, and only when he observed the other passers-by did it take on a furtive expression.

"Of course," said Attila, "but do you think it's easy to find? I've been asking and searching for a while now, but without any luck at all so far. I don't suppose you know of anything?"

He said this without much thought, maybe just a little belligerently.

They were still standing at the postbox, when the other man said: "I don't suppose you'd like to come with me and have a look at our place? We're planning to let our bedroom to boarders. We're going to move into the smaller room and the children will sleep in the lounge."

Attila had learned a fair number of dialect expressions during his short stay in the city, but there were some things he still had trouble 
with. The hotel guests especially, often used words he didn't understand. But this person here was speaking what would almost pass as High German, a bit harshly, perhaps not exactly the way it was spoken in these parts, but Attila could understand every word clearly, and this man was talking about a room which he was willing to let him. There was no way he could have misunderstood.

He was offering him a room! He had even brought the subject up in the first place! Attila was overjoyed. Frau Maria would be so surprised. He would get himself a room without having to bother any of her 'contacts'!

"We don't really need to take in boarders," the other man continued, "but I'm sure you know what it's like, the children need such a lot. The older one wants a car of course, all his friends have got one already, there's such a need to conform. And the younger one, he's only fifteen, he has to go to Casablanca with his class. Do you know where that is? Not exactly? It's a seaport in Morocco, in North Africa. Never been that far away myself, never. But almost all the other children in his class are going there at the end of the school year. It wouldn't be right to leave him out. No, there's just no way I could do that to him. He'd get some sort of inferiority complex!" He tugged at his goatee. "No way at all. The other children's parents know me you see. I just couldn't let my youngest go through that. Princess, I keep saying: I'd rather go without food before I show my children up in front of the others." He paused for a while. "Princess is my wife, you know."

Attila thought he had never heard of anyone with a princess for a wife. The men either hushed up the existence of their wives altogether or they included them in the conversation with a host of smutty comments.

They were both still standing beneath the lantern at the yellow postbox.

"What would you think of coming to have a look at the room right now?" asked the other man.

"What, now? But it's dark already. I don't want to put your wife out or anything," answered Attila. But at the same time he was thinking: If I went with him now, I'd know straight away whether I could take the room or not, and then tomorrow I'd be able to tell 
Maria. Let's hope that Princess isn't asleep yet. He had to smile when he thought of 'Princess'. He imagined a small, fragile woman with cunning, blinking eyes.

"She always waits up for me," the other man told him. "There'd be no problem if you wanted to come right now."

They set off and turned into the next main street. The brightly-lit shop windows, the neon signs, the iridescent lights split up into thousands of facets, the illuminated rotating signs with their jerking movements, switching constantly on and off, the headlights of the vehicles constantly flitting past, all made the pale face of the bearded man seem a little more animated and friendly.

"By the way," said the man, "my name is Hartmut, and we met at the office. I had to work late today. You know what I mean?"

Attila understood.

The passed a few women that Attila knew from the hotel, then walked along a dimly-lit alleyway. After some time, they stopped in front of a large building. It looked good from the outside, with a very middle-class appearance and probably built towards the end of the last century. Large curved balconies were attached to each floor, the walls along the staircase were clad in marble and the doorman had a sign on his door which read Portier. But when the two men entered the Hartmut family's apartment, Attila began to wish he hadn't come at such a late hour. He couldn't see any light in any of the rooms and was embarrassed when his host invited him in. Hartmut had switched on a small wall lamp, whose silken shade dimmed its light. Now he opened one of the many doors, stepped into the living room and switched on the light. Attila followed him.

At first he didn't see her at all.

He looked around the room. In the middle of it there was a large table with four massive German Renaissance chairs, a settee and a huge sideboard, dark heavy drapes and a crystal chandelier. All this absorbed his attention. Only when he heard a noise from a corner did he look around.

In this corner sat a large woman, clothed in a dress which was covered in flowers. She must have been waiting in a completely darkened room. She might even have nodded off, because when Hartmut switched on the light and the room was dimly illuminated 
by a forty-watt light bulb, she rubbed her eyes and blinked as if she had been blinded by a spotlight. She yawned loudly to begin with, and finally asked: "Who's that man with you, Daddy?" The tone of her question was not really indignant, it was more suspicious than anything else.

"Look, Princess," said Herr Hartmut, "this is our future lodger. Please allow me to introduce you." He made a sweeping gesture with his arm. There was a little pause, and then Attila remembered that he hadn't yet told the man his name. "Horvath!" he said quickly.

"That's right, Herr Horvath," repeated the man. "He came to see me today in the office and I happened to mention that we were thinking of letting our room. Herr Horvath has been looking for a room for himself and his young sister for days. I think they would suit us. Don't you think so, Princess?"

The two men had approached the chair where the woman was sitting, and Attila bowed slightly.

"Give me your hand, Daddy, come and help me up," said the woman. She reached out with her right hand, the man gripped it and pulled the woman from the chair. She was huge, in both stature and girth. She stretched her hand out towards Attila and said: "I'm delighted that you're interested in our room. Please come in. Have a look for yourself."

She started to move, but she didn't walk the way a normal person would, lifting one foot and putting it down again at some appropriate distance, shifting the weight of her body slowly from the leg behind to the leg in front, doing the same with the other foot, and so moving forward, step by step. Instead she shifted her weight to one side with a slight swinging motion, allowed her foot to glide forward and swing back again. This caused a waddling, swinging motion which seemed to be in danger of being interrupted at any moment by her toppling over.

Now that Attila could see the woman in her entirety, he was shocked. An enormous, amorphous mass of fat and flesh was approaching the door in front of him. The bearded man sprang around her, agile and graceful, opened the door and switched on 
the light in the neighbouring room. The woman snorted. With some difficulty, she inclined her head slightly back towards Attila, who followed hesitantly. It was almost impossible to grasp how she managed to turn her head at all. Her neck and chin and cheeks all seemed to be of one piece and her head was stuck onto her rotund body, like a cork in an enormous bottle. Attila stood behind this woman like a small fellah in the shadow of a colossal statue of Abu-Simbel.

All three were now in the bedroom and, with an air of selfimportance, as if she were speaking on a matter of global significance which could influence the future of mankind, the woman explained that she and her husband had their beds here, and over there, she paused, and pointed towards the wall, were the beds of the two boys. The two children had folding beds which would be moved into the lounge, she added.

Then she pointed to the picture on the wall. A badly coloured photograph of two boys. The woman was still speaking in her pompous manner and Attila wasn't really listening, he found her voice unpleasant. He stared the whole time at the wall just above the picture. This made the woman assume that he was interested in her children. She told him all about the two boys, how old they were when the photo was taken and how old they were now, and then where they were now, at the cinema, she told him which film they were watching, that she had already seen the film and how much she had liked the film, that she had cried a lot when it came to an end and then she wanted to know whether Attila had seen the film too but didn't allow him any time to answer but kept on telling him that she was often by herself, that her husband had to work a lot of overtime and couldn't go to the cinema with her very often, that she lived for her children and that these days the children left her alone too, that the boys were out a lot and that... She had a lot more to say besides.

But Attila, without allowing himself to be distracted, had seen two tiny brown specks above the picture, which were moving slowly in single file. They seemed to have been hiding behind the picture. Now they were climbing up the wall. The distance between the two specks was changing constantly. The front speck would stop or 
slow down, then it was the turn of the other one, which was nevertheless remained behind it. Some obstacle invisible to the human eye obviously had to be overcome. What were those specks? wondered Attila. Were they perhaps the souls of the two boys, conjured up out of the picture by their mother? Where were they going? The specks climbed higher and higher, almost diagonally, in the direction of the neighbouring wall.

The woman hadn't noticed them. She was talking about her two children. She told Attila about their birth, their first steps, their first words. She talked about their first day at school and about their second first day at school. She talked and talked... But the men weren't listening any more.

Herr Hartmut seemed to have followed Attila's gaze. He grew slightly annoyed, and tried to distract his guest from the sight of the two specks. He tried to say something, but the woman was not to be interrupted in her tirade. She reprimanded her husband, and pointed out that surely she had to tell their guest about their children and how good they were. Otherwise he might be of the opinion that they were just any old badly brought-up individuals.

"Isn't that right?" she asked Attila.

Attila nodded. He didn't dare contradict this hulking, monumental person. He was genuinely afraid of this vast accumulation of fat and flesh, and just nodded his head. He would have nodded his head to anything she might have said.

Could we really live in this house? he thought to himself Poor Olga! She wouldn't be able to cope. He glanced quickly back at the man, this slim, gaunt man with his goatee and as he searched again for the two specks - they'd advanced quite a bit in the meantime he thought, how could these two people possibly live together? And to think there are children as well! This man lying on this woman! He shuddered at the thought of it.

He caught sight of the two brown specks again. The first one had reached the corner of the ceiling and now Attila could see why they had been so eager to get up there in the first place. At the corner where the vertical wall and the ceiling joined together, there was another brown speck. It was just sitting there, almost stationary. Every now and then it would make a sudden movement forward 
and then back again, but it never moved down the wall or up onto the ceiling.

The fat woman was still talking. She had finished with the topic of her children. She stepped towards the beds to show them to her guest. Attila was to be convinced of the quality and cleanliness of the furniture.

But he was still looking up at the ceiling and watching as the leading brown speck climbed up closer to the sitting one. That one retreated a little. The other followed. The first one moved aside. The other one followed again. The game was repeated. Then the speck which had been sitting in the corner remained stationary and the other one moved very close to it. It now looked as if there was only one large speck which was thinner in the middle. At this very moment, the third speck, that is to say the second one coming up from below, reached the other two, or, as they might be referred to now, the larger speck. This larger speck remained still for a moment and the third speck, or so it seemed to Attila, seemed to want to incorporate itself into the larger one in order to make the latter even bigger. But only for a moment. Then all three detached themselves from the wall and fell to the ground, making a small hard sound.

Herr Hartmut rushed to where the three bodies had fallen. He didn't seem to care now whether Attila was watching him or not, perhaps he had forgotten his guest altogether at that moment. With his right foot he stamped on the specks, each of which tried to escape in a different direction on the floor. Attila watched as Hartmut moved his foot in its high black boot back and forth several times, pressing down hard as he did so. It was disgusting. He preferred not to look.

And Olga, he thought, she'd have to stay in bed all day and be tortured by these creatures.

The woman stood next to the bed and tried to lift the mattress up to show him the quality of the base. In order to do so she had to lean forward quite a lot, which in turn caused her dress to be pulled up by the vastness of her backside. Attila could see the terribly pale skin above her stockings, which, because of the excessive diameter of her legs, came up only slightly above her knees. He could still 
hear the sound of falling and the scraping of the boot in his ears, and now he saw before him this picture: A swelling white bulge, increasing as it rose, irregular, bounded by the hem of the dark dress, as if by a curtain. He saw an enormous balloon, constrained by the material of her dress, and at the same time, as if to complete the grotesque picture, the face of the bearded man appeared from behind the vast dome of her figure. Herr Hartmut had noticed with satisfaction that his guest was watching his wife, or at least what could be seen of her, as he concluded his act of extermination. He hurried to help her and went to lift the mattress on the other side. His bearded face danced to and fro above the balloon.

How could we live in this house, Attila thought again.

He couldn't stand the sight any longer. He looked away. There was a blood stain on the floor, a smudge mark on the wall. Attila's face grew pale. He felt quite sick. He felt as if all his limbs were throbbing. His stomach, what was the matter with his stomach? Attila staggered, reeled. He turned around quickly, and without concerning himself any further with his hosts, he barged through the door. Everything reeled faster and faster as he made his way through the room, opened the door to the entrance-hall and searched, frantically feeling his way in the darkness, for the front door. Herr Hartmut came after him. The light was switched on and the narrow, bearded head sprang towards him. From the bedroom came the sound of clattering and rumbling. Had the colossus fallen? wondered Attila. The younger son wants to go to Rhodes. Didn't his father say Rhodes? Why Rhodes? No, it was Casablanca. We'd be living in Casablanca here, beneath that dancing colossus on the blood-stained floor. It was horrible! Horrible! That large, motionless mass of a woman dominating the room. And every evening, the whole tribe of them would be dancing round our beds, while the black-bearded, pale moon with his grotesque grimaces would rise above the horizon, and now, now, for all I know, it could be the head of some fanatical dervish, appearing at this very moment above mine. Attila breathed out. He was expecting the sacrificial knife.

But no, it was Herr Hartmut, who had followed him out and was asking him whether he felt sick, what was the matter? 
Attila collapsed into a chair which stood next to the front door and let his head hang down on his chest. His eyes were half closed. $\mathrm{He}$ would have preferred to see nothing more of his surroundings. "Which way is out?" was the only reply he could manage.

"Come on," said the man. He gripped Attila under the shoulder. "I'll help you." He guided him towards a narrow door and opened it. It was the toilet.

"No!" cried Attila, and swung around violently.

At that moment the plump figure of the woman waddled into the room. "Daddy! Daddy," she screamed.

So she hadn't broken up into a thousand pieces after all, was Attila's first thought when she reappeared. "Air! Air! Fresh air!" he cried.

Suddenly he knew which door led outside to the staircase. He bolted towards it, tore it open and flew out.

"Daddy, what sort of a monster did you bring home," he could hear the woman scolding behind him. He also heard the gaunt man soothing her: "My Princess, my Princess." He had already reached the front door of the building, when he heard the noise of the apartment door being thrown violently shut. 


\section{The View through the Lens}

The weather had changed the next day. As Attila crossed diagonally through the Inner City to the Tourism Office, a layer of sun seemed to envelop everything. The usually dull windows shone in bright colours, yellow and green, blue and orange. Some old men were leaning against a wall in a spot sheltered from the wind. They wore grey, worn coats, one or two of them were smoking oldfashioned pipes, and every now and then, one of them would mumble a few words that the others usually didn't understand and a long debate about its meaning would follow. Two women were pushing their prams to and fro in front of them, and the old men followed the young women back and forth with their gaze. They shook their heads and squinted into the bright sunlight. Attila was tempted to stay by the sunny wall for a moment, but decided to go in. The trams rang their bells as if it were springtime. The light wind that blew the white threads of gossamer through the streets, lifted the exhaust fumes of the vehicles from the narrow valleys of the streets and dispersed them in the silky blue heights. A young man passed Attila on his bicycle, whistling the melody of a popular song. The houses were without sharp corners, and a slight halo encircled the street lamps.

Attila decided not to tell Maria about his visit to Hartmut's. What for? Had it all even been real? Did that kind of thing even exist? Blood sacrifices in the middle of the city! A pale, bearded priest in an ecstatic dance before some kind of amorphous mother-goddess, before the personification of flesh itself, holding himself up, swaying, and then falling down and burying everything. Flesh, an explosion of flesh. A mountain of flesh. Blood staining the floor red. And every evening that white moon over the horizon, in its enraptured dance. Casablanca? Rhodes? No, further back, much further back. The dark specks, the souls of the children sacrificed to a deity of flesh. He didn't know anything about them. All he knew was that there were certain things they demanded. Sacrificed, sacrificed to the darkness of the city. 
Bright sunlight enveloped the houses, shone in all the windows.

At five minutes past four, Attila reached the rooms of the Tourism Office. Frau Pokorni was already standing outside the door waiting for him. "You're not especially punctual," she said. "We have to hurry, the professor gives lectures in the afternoon. He's a scientist you know. He's got a beautiful house out in the Cottage District, fairly big, perhaps there might be space for you there. You could even look after his affairs when he's away at conferences and lecture tours."

They had shaken hands in greeting and Attila was still holding her right hand in his. He looked into her face. He noticed her slim figure. He thought again of yesterday evening. He pushed the image away. He hadn't seen it! Hadn't seen it!

They walked to the next tram stop and got on to one of the waiting trams. There were a lot of people in the carriage and Attila was pressed up close against Frau Pokorni. "Maria!" he wanted to say, his head was close to hers. He looked at her, and said nothing. The tram rattled from stop to stop and the noise it made, together with the noise of the cars that passed it and crossed its tracks, was so loud that Attila had to concentrate to understand the words of his companion when she said: "He specialises in small animals." She meant the professor, of course.

Behind Attila stood a man who pushed his briefcase into the back of his knees and on his right he could feel someone's bulging body pressing up against him. It belonged to his neighbour, a woman of about fifty, whose hips were obscured by great mounds of fat. That hideous flesh! He could feel it all so close: Frau Hartmut. Rhodes. Casablanca. Child sacrifices. Blood. Blood. He could smell it. The bloodthirsty Kali. Maybe the professor specialised in bed bugs too? On Attila's left stood a man in a leather jacket. At each jolt of the tram, he was almost thrown on top of Frau Pokorni. He kept trying to grab the strap that Attila was using. His big rough hand with its dirty fingernails kept brushing against Attila's, and it fluttered like a scared crow around the leather strap for a moment, before it found a grip above the other man's hand, leaving his body to swing back to its original position.

"Haven't you heard of him?" asked Frau Pokorni. "But then, 
it's a silly question really, how could you know anything about a highly specialised discipline like that. I don't know what I was thinking. But if the professor will let you stay with him, I have a feeling that you might well find his creatures fascinating. Some of those tiny life forms are remarkably beautiful. He's often let me look through his microscopes. Those minuscule specks are just amazing, arranging and structuring themselves in an endless number of ways, it's like a world in its own right!"

For a moment, all the passengers seem to be suspended diagonally in space, as the carriage moved swiftly round a bend.

Attila thought he saw a collection of fuzzy brown specks all around him, then things seemed to rearrange themselves again. The hand, the fingers gripped the leather strap and the faces swung to and fro while the flesh of the fat fifty-year old woman pressed itself up against him - how much longer was this torturous closeness going to last, he thought - and then he looked into the face of an Artemis, into the large brown eyes of Maria.

But Frau Pokorni was talking away, paying no attention to any of the unpleasantness around them, talking about the professor, his laboratory animals, talking about his discoveries, his tables and drawings. Attila could sense that the woman was somehow trying to shield each of them from the other, with all her chatter about this other man, with all these irrelevant, unimportant trivialities that didn't interest him in the slightest. Sometimes he asked a question himself. Such and such seemed new and peculiar to him. He'd thought such and such was quite different. Not that he'd suddenly become interested in zoological issues, not that he really wanted to know the answers to what he was asking about - he generally forgot the woman's answer almost immediately - he was just playing the game. They could both feel it. It was a game. A game that allowed them to put off telling each other the important things they had to say.

The tram travelled on further towards the outskirts of the city. The streets were wider here, and the houses more attractive than those in the area around Attila's hotel. Here there were often small gardens in front of the houses, and Attila thought for a moment about his sister's dream. At a circular place, the tram went around 
in a loop. It was the final stop. The people got out and disappeared in several directions.

Attila and the woman walked along an alleyway. The trees had shed almost all their leaves. The sun drew the shadows of the bare branches in confused lines onto the cobblestones. Every now and then, a swarm of dried leaves rushed along the guttering. Frau Pokorni and Attila were soon alone in the alleyway. It was quiet. The woman didn't say any more. Attila was silent too. It seemed to him as if the walk together would never end, as if the professor's house was still a long way off. But then, suddenly, they were there. It couldn't be the house he lived in, the shiny brass plate at the gate said DEPARTMENT OF ZOOLOGY. When Frau Pokorni pressed the doorbell, they looked significantly at each other. They both knew that in their silent walk together they had said far more to one another than during their lively conversation in the tram. But for each, it was a private knowledge, one based only on their own personal experience, and even at the very moment that her fingers touched the button and their eyes met in understanding, and each assumed, no, believed, that the other was feeling exactly the same way; at that very same moment, each was still holding back a minute piece of themselves, a small piece of their own personal being.

An elderly man opened the door. He greeted Frau Pokorni like an old friend. He took their coats in the foyer and showed them in.

There were a number of large wooden crates in the room, and a collection of ring binders, rolls of paper, and stacks of stapled documents rested up against one of the walls.

"Is the professor off again on another one of his field trips?" asked Frau Pokorni. The old man appeared not to have heard the question, for he didn't reply. He showed the visitors into the next room. There were crates here too. There were also a number of tanks, with various small animals inside. Some of the glass tanks were empty, in others all that could be seen was grass or sand.

The two visitors stood alone in the room for a moment, uncertain of what to do. They looked around, searching for somewhere to sit. There was an upholstered chair right next to them and another one standing in the opposite corner. Frau Pokorni sat down in the chair 
nearest her and Attila pulled a crate close to the chair, sat down and found himself opposite a lizard, which blinked at him as it sat in its glass tank.

He pointed to the creature and said: "It's got my sister's eyes." The lizard remained stiff and motionless in its tank and looked out at them, or maybe it wasn't looking out at them at all. Maybe it couldn't see through the glass wall. But then again, maybe it could not only see through the glass, maybe it could see through the people too, and even further, right through to the sunny wall in the warm South where it had come from and which was its world, a paradise-like world, which it still held on to, kept deep down in its eyes, a bright, sunny world, which the animal's dark, shimmering pupils concentrated into a mysterious blackness, a blackness which reflected the two heads of the humans.

"She must have beautiful eyes," the woman said.

"Beautiful and full," Attila replied.

"Full?" repeated the woman. She didn't know what he meant. She stared at him.

"Yes, full. Full of bright memories of our homeland." Attila looked the woman in the eye. "We're all living in a cage, a glass cage."

"We're not living in anything of the kind," she contradicted him immediately. "Glass cage? We've got countless possibilities to choose from. Who's stopping us? Take now, for example, we could leave here any time. Here or anywhere. Take it from me! I know all about cages. And you, you escaped from your homeland too, didn't you, you escaped from your cage and left. I feel completely free, I live the way my intellect tells me and my conscience lets me. It's only reptiles, like these lizards, that feel at home in any cage they end up in and are as happy there as anywhere."

"Is that true? You're really happy?" he asked.

She shrugged her shoulders.

He smiled. He wondered if she was being serious. She seemed more beautiful to him today even than the day he'd seen her for the very first time. She'd obviously been tired back then, stressed. More resigned to her fate perhaps. He lowered his eyes. The glass tanks came into view again. "What about the glass cage called 
Pokorni?" he asked.

She remained silent for a moment. It was quiet again in the room. The lizard didn't move a muscle. It could have been dead for all Attila knew. Finally, in the twinkling of an eye, it swept its delicate eyelid across the shiny brown pearl underneath.

The woman's hand touched his. "Quiet," she said. "Please don't talk about it."

At that moment, the professor appeared. He kissed Frau Pokorni's hand and she introduced Attila to him.

The professor apologised for the mess and explained that he was about to go away on leave. He moved the second chair from the corner and sat down with them. He asked which town Attila came from and what he did for a living and some more besides. His questions were no different from the questions of all the other people Attila had met up till now. He felt the professor was only asking because etiquette demanded it, and let his thoughts drift elsewhere. Frau Pokorni was embarrassed on his behalf, and was glad when the professor turned to her, assuring her how pleased he was that she had taken the trouble to visit him before he went off on his trip.

Attila looked closely at the man sitting opposite him. He had cold staring eyes, which observed him from behind his glasses in a disquieting way. Attila felt uncomfortable. He sat on the crate and looked at the lizard, while one of his legs swung freely. There was another tank underneath the tank of reptiles. But Attila couldn't make out what kind of animals were in there. There were some inconspicuous-looking grey balls, and something seemed to push up against them every now and then. Attila heard the professor inquire after a certain Georg Schmidt. He was obviously some acquaintance he and Frau Pokorni had in common. The woman said that this Schmidt was drinking again and the professor shook his head.

"What a pity," he said. And after a short interval he added: "It's a pity too, that we don't meet up together more often. They were such nice people. There was that pianist. What was his name again? Oh yes, that's right, Adam Blumenstock, and that young 
Lindberg. Then there was Muschler, the lawyer, and his wife - I heard those two got divorced - and that singer, Ida. Oh, and Herr Walzek! What became of him? Have you heard anything about him?" But he didn't even wait for a reply, in all likelihood the fate of Herrn Walzek was of no interest to him at all. He continued on immediately: "Isn't that just the way of things. We were all so young and unsettled in those days. A lot of the others came from rural areas, you yourself, if I remember rightly, came from a foreign country even. Yes, and then everybody settled down. Blumenstock was the first one to leave. He went off on that concert tour. And I, well, you can see for yourself, I'm packing up again too."

Attila was only half listening to the professor's words. What interest could he possibly have in Walzek, whoever he was, and the singer Ida, the divorced lawyer Muschler or Adam Blumenstock? He gazed past the speaker and into the glass tanks. In the glass wall of one of the empty ones, sitting in the middle of others stocked with several reptiles, he saw an alleyway and two people. A woman and a man, Maria and himself. They were familiar with one another, had their arms around each other and sometimes they stopped and kissed. And it was clear to him they wanted to stay in their cage for always. Suddenly, there was something moving in the glass tank next to him. It was the lizard, and it shot over to the opposite wall. Attila saw his sister looking out at them from the tank. She was shouting something to him, coughing and waving her arms, and from the grey, previously unidentified ball in the lower glass tank, the head of Herrn Pokorni, with a shiny face and bulging eyes, suddenly pressed itself up against the glass wall. Attila turned his eyes away. He didn't want to see it any longer.

He looked across at Frau Pokorni. Be quiet, she'd said. Please, don't talk about it. Don't talk about it. Yes, 'talk', she'd said it so simply. And then this professor arrived. I wasn't going to talk about it anyway. I was going to talk about something completely different. Talk, she'd said! Had she made a mistake? No, she most certainly hadn't! Had he perhaps pushed over one of the glass cages with a sudden impetuous movement?

He's getting impatient, thought the woman, who had noticed his 
glance. Christ, we've only been here five minutes. I can't come right out with the reason for my visit. Especially seeing as Albert is just about to go away again. He thinks I've come because I wanted to see him before he leaves on his expedition.

A young man entered the room and passed the professor a piece of paper. A woman in a white coat walked past. The professor apologized, got up and signed the piece of paper. He spoke to the young man as he bent over the crate.

The two guests looked at each other. The woman nodded to Attila. "Be patient," she whispered.

Attila smiled. He wondered whether he could call her by her first name now. "I'm not being impatient," he whispered back to her, "how could I, with a picture like that in front of me." He pointed towards one of the glass tanks.

She looked at the empty container with a blank expression.

He saw that she didn't understand him and added quickly: "In the glass! The reflection!"

And now she saw it too. The way their heads were reflected in the pane of glass, they seemed to be touching each other, sometimes they even overlapped, almost as if one was taking possession of the other. She smiled.

The professor returned to them. All she had time to say was, "not one of your cages again." Attila couldn't decide whether she meant it ironically or not.

"Well, Maria, if you and your guest are agreeable, I'd like to suggest that you both come on in," said the professor. They got up. Attila glanced again at the empty glass, then he followed too. Guided by the scholar, they passed through a number of rooms in which young men and women could be seen occupied with different tasks. As they passed a row of microscopes, the professor asked: "Would you like to have a look?" He was speaking to Attila.

A man with a thin, pointed beard, busy with all sorts of glass plates and slides, stepped towards them. He placed one of the slides under the lens and invited Attila to sit down. With the naked eye, the three tiny specks on the glass were only just visible. But now, when Attila looked through the microscope, he was overwhelmed by the rich variety of forms he could see. 
Maria and the professor stood at a window and looked down on the street as it basked in the autumnal sun. The professor remarked that this time he'd most likely be away for a whole year, or even longer. Maria wasn't sure exactly where the expedition was headed, so the man explained it all to her in a convoluted sort of way, he also explained what kind of animals he hoped to find there, his words flowed out in a continuous stream. Maria knew that once he got going he was impossible to stop. So she decided to ask him straight out whether he knew of anywhere for Attila to live.

At first, he said nothing. "Oh yes, I see," he said at last, "I understand, you were in one of those refugee camps for such a long time too, and so you empathise." And in fact, he knew nothing else at all about his visitors. The only thing he knew about was the organs of small animals. He knew all about their metabolism, their reproductive cycles and their behavioural patterns. So all he could find to say was: "You know, I'm so occupied with my travel plans that nothing springs to mind right now."

"What about your place?" asked the woman. "Your housekeeper is all alone in that great big house when you're away. Couldn't you maybe..." She didn't finish her sentence, just looked expectantly at the man opposite her.

"What on earth are you thinking of, Maria," the professor replied, "that would be quite out of the question. My housekeeper is going off to see her daughter while I'm away. It's all been arranged. She's been wanting to do that for some time. I'm not quite sure, her daughter's sick or something like that. Or no, it's the other way round, she's had a baby and the old woman wants to help her. Well, how could I deny her a request like that. Besides, I can save a lot of money if she takes unpaid leave. And they'd be by themselves, I couldn't have strange people in my house by themselves, I'm sure you can appreciate that. If it were you, that would be a different story. But as it is, I don't even know these people and you, I'm sure you don't know them all that well either. It would be sheer carelessness. In fact, I think I'd really have to say it would be irresponsible..."

He kept on talking, adding more and more sentences, giving good reasons, lots of good reasons. The words seemed fuzzy to 
Maria. Down on the street, she could see the odd person passing by. With the trees bare of leaves, it was possible to watch them for a long way down the straight alleyway. They each seemed wrapped in a cloak of bright mist, travelling almost weightlessly towards some far-off goal. Each of them walked alone, and finally disappeared into one of the front gardens. And although a few moments ago she had perceived the golden gleam of the sinking sun as a blessing, a certain sadness now took hold of her. It now seemed to her as if the sun was caught in a brownish-red swamp that was moving sluggishly along the horizon. The bare railings of the trees stood sombrely in front of it. The further the strips of light distanced themselves from the glowing centre, the more blue was mixed into the brown, and a seam of dark violet formed a border against the crystal-clear sky. Maria shivered when she saw this sky, even though she was standing in the well-heated room in the laboratory. The professor next to her was still talking about his animals, about his expedition and about his scientific methods.

Maria only interrupted him once more, to say, "Do you think perhaps it could have been his doubts, those existential dilemmas of his, that started Georg off drinking again? That old problem of how to reconcile the spiritual and the material worlds, which he took so seriously? He used to be one of our most passionate debaters, do you remember?"

But the professor didn't even notice the attempted change of subject. He continued his monologue undisturbed.

Attila was still sitting in front of the microscope. He wouldn't have thought it possible that these tiny life forms could be structured in such a complex way. When he lowered his eye to the barrel, a new perspective opened itself up to him. He saw an almost circular head, all out of proportion to the other parts of its body in size. Eyes bulged out from the creature's front section. They reminded Attila of the gleam of the professor's thick glasses. The whole thing looked like a gigantic bald head, with a collection of arms and legs stuck on the sides. For where would there have been room for any sort of torso or body? Or maybe that limb that tapered off like a tail might be what you could call the body. Attila didn't know. He would have needed to ask one of the specialists 
present. But he didn't want to do that, they would have told him too much, in too great a detail. They would have dissected the creatures into their many parts, would have told him which species and subspecies they belonged to and finally he, Attila, would have had in front of him, not a miraculously rare creature any longer, but a mere object, on an ordinary old plate of glass. They would have told him that it belonged to the species of the orbitidae, that those thin threads were called pseudostigmal organs and that they were organs of perception, which reacted to every vibration and helped the blind animals to orientate themselves. But Attila preferred to observe unenlightened the long, whip-like, softly curving limbs. Perhaps, he thought, they might be feeding tools, maybe they used them for locomotion. Some of the legs had a claw-like pointer at the end. The odd thing was that these thin limbs stuck out from the ball-head randomly in all directions, to the front, to the left, to the right, in irregular groupings, even straight up and down. Maybe these creatures didn't have any conception of depth, maybe all that was real to them was the surface that their head-body was moving along, maybe the sum total of existence for them was that which their long elastic tentacles could actually grip and hold.

Before examining the next slide more closely, Attila looked over towards the two people deep in discussion at the window. Maria was saying something to the professor, which he didn't seem to hear properly. Attila couldn't hear what they were talking about, they were too far away.

It's a whole new world, he thought, and looked through the lens again. A world with its own laws, with its own forms and rules and habitats. A beautiful world, really. It's just that for someone like me, looking into it is a bit like peering through a stranger's window, it's almost a bit frightening. He was concentrating on the second speck now. This creature's anatomy seemed dominated by a long, powerful proboscis, which separated off, dividing the body into a short front and a longer back section. While the front part appeared smooth-skinned, apart from a few small wart-like bumps, the back section was covered in short, hard bristles, bundled into little bunches of three or four, and protruding at irregular intervals. The little legs - this time recognisable as such - were covered in fine 
hair. Small, brush-like slippers completed the picture.

Attila looked up again. The other two were still standing at the window. The professor was speaking again and Frau Pokorni was silent. Pokorni! Large, warm slippers. Arms and legs covered in bunches of hair. An insatiable proboscis probing restlessly for food. Roast pork. Gateau. Wine. Dark hair sticking out through the carelessly buttoned shirt. Braces, shiny and worn, greasy. A tiny head, with pimples sprinkled over the smooth-shaven face. How had she come to marry this creature? What could have possessed her? The slide. There was something else lying on the slide.

Attila turned his attention to the third speck.

"So, how do you like them?" asked the professor. Attila had just been about to adjust the lens properly. He looked up. He'd only just seen the blurred outline of the last of the creatures.

"A fascinating discipline, wouldn't you agree," said the professor. "I always find it quite remarkable, when I see evidence of the extraordinary extravagance and variety that nature has equipped its creatures with. Even the simplest forms will display a wonderful richness in design. Some of them seem almost cheerful. Don't you think?"

Attila got up and looked towards Maria as if he was trying to read the outcome of her discussion with the professor in her face. Her eyes avoided his. They looked at his shoes.

"Cheerful?" he asked, "I suppose you could call it cheerful. I think they look more threatening really, almost sinister. They' re so different, like some sort of unknown beings from another world. A world where each bit is still isolated off from everything else, much more so than in our own. Here we've got a head all by itself on some legs with nothing else, and there's a body here with no head, just a greedy proboscis which looks like it's out to devour everything in its path."

The professor just smiled. "You've got a very vivid imagination, Herr Horvath. But generally speaking, these little creatures behave much like the more highly developed ones, human beings included. Every one of these tiny specks is actually intricately structured. It's just that with some of them, we don't yet know what their role 
in the world of nature is, what they're there for. But then," he made a helpless gesture with his hand, "I suppose we don't really know the answer to that one when it comes to some of our fellow human beings either."

Maria looked at Attila's shoes. They were worn and the upper of one was split above the ball of his foot. Now he's going to grace us with one of his clever remarks, she thought, meaning the professor. It's always the same. He's incurably self-indulgent when it comes to his own rhetoric. Those soles. They're not going to last much longer. Will he even be able to buy a new pair of shoes? A violin maker. Where are the violin makers in this city? I've never seen one, but there are bound to be some somewhere. Delivering newspapers at the moment. Is this one pair all he's got? Oh God, how they talk, talk, talk. Doesn't this Attila realise that it's all in vain? Surely he must know by now. His eyes told me so before. He knows. But he doesn't care. He's talking on and on, as if he couldn't care less. Her glance crept up Attila's trouser leg. Threadbare as well. How much longer? She looked into Attila's face. He obviously likes this kind of conversation. Not me, I've had enough for one day!

She picked up her handbag, which she had left on the windowsill, and walked slowly across the room towards the door. The men followed her, still talking intently.

What a wasted visit, she thought. Her overwhelming emotion was one of sadness. On the one hand it was because she hadn't managed to help this man she had taken under her wing, but it was perhaps made even more cutting by the fact she had always thought the best of her old friends up till now, especially Albert.

When she was back on the street again, walking next to Attila, she was very quiet, while he chattered on about the impression his new acquaintance had made on him. He dismissed Maria's references to the futility of their visit with the observation that for him it hadn't been futile, because he had met with a great intellect. Maria only smiled mockingly.

They walked down the same alleyway again. But the sun had gone down behind the houses. The street looked grey and inconsequential, the trees seemed like bizarre ghosts, silhouetted against a 
dull sky. It was cool, and Attila buried his hands deep in the pockets of his thin coat. He had turned his collar up. He was freezing. He avoided addressing the woman directly. He didn't quite know whether to say 'Maria' or 'Frau Pokorni'. They were both relieved when they could hide among the busy traffic of the streets, and as they moved further towards the centre of the city, they gradually moved closer to one another. Maria asked him about his past and he felt now that it wasn't just out of curiosity, but a real interest.

Finally, she invited him for a meal in a quiet restaurant. They sat there for a long time at one of the small tables. Attila spoke of his childhood, of his homeland. Her black hair shone and her hands met Attila's across the top of the table, and suddenly it came quite naturally to him to call her 'Maria'.

When they left the restaurant a few hours later, Maria linked her arm through his. She, elegant, he a scruffy-looking tramp. They had to hurry because they wanted to buy dinner for Attila's sister. Maria had promised to come with him. She was going to meet Olga.

She didn't try to justify her relationship with this man. She had helped him, much as one would help a child. And of course, she had found the casual contact with his hands pleasant. But she didn't try and justify that either. It had just felt right.

She went to the hotel with him and met his sister there. She stayed for a long time. She tried to talk to Olga. Attila had to translate frequently. But in spite of that, in spite of all the words she didn't understand and those that were in turn not understood, she felt some kind of contact with the girl. She admired Olga's calmness. She admired her trust in everything her brother told her and whatever fate had in store for them. 